Portland State University

PDXScholar

\title{
Comments on the Emergence and Persistence of Inequality in Premodern Societies
}

Kenneth M. Ames

Portland State University, amesk@pdx.edu

Follow this and additional works at: https://pdxscholar.library.pdx.edu/anth_fac

Part of the Inequality and Stratification Commons, and the Social and Cultural Anthropology Commons

Let us know how access to this document benefits you.

\section{Citation Details}

Comments on the Emergence and Persistence of Inequality in Premodern Societies Kenneth M. Ames Current Anthropology, Vol. 51, No. 1 (February 2010), pp. 95-96

This Response or Comment is brought to you for free and open access. It has been accepted for inclusion in Anthropology Faculty Publications and Presentations by an authorized administrator of PDXScholar. Please contact us if we can make this document more accessible: pdxscholar@pdx.edu. 


\title{
Comment: Intergenerational Wealth Transmission and Inequality in Premodern Societies
}

\section{Comments on the Emergence and Persistence of Inequality in Premodern Societies}

\author{
Kenneth M. Ames
}

Department of Anthropology, Portland State University, P.O. Box 751, Portland, Oregon 97207, U.S.A. (amesk@pdx.edu). 14 X 09

This set of stimulating papers undertakes one of the central tasks of the human sciences: explaining the origins, evolution, and persistence of permanent inequality in human societies. The papers test the hypothesis that intergenerational wealth transmission is a key —if not the key-process in the persistence and evolution of inequality. Crucial to their test is how wealth is transmitted, the degree to which it accumulates or erodes across generations, and the forms it can take. They identify three broad categories of wealth: material, relational, and embodied. Material wealth equates with our common definition of wealth (e.g., land, livestock, jewelry, slaves); relational wealth refers to an individual's "social value" but is essentially a person's place in social networks, including the number of connections they have. Embodied wealth includes somatic wealth (health, strength) but is also knowledge and skills. The papers incorporate reproductive success as a measure of embodied wealth rather than as a consequence of it. These classes of wealth take different forms, occur in different proportions, and have different relationships in different societies, contributing to the variety and complexity of evolutionary trajectories and social forms. The authors of these papers investigate this variability by looking at case studies from four broad classes of food procurement economies: hunter-gatherer, horticultural, pastoralist, and intensive agriculturalist. Rather than relying on ethnographic narrative, their comparative work rests on quantifying intergenerational wealth differences with a measure they label $b$ and wealth itself in the three wealth categories, using standard Gini indexes.

The studies are far too rich in results to discuss them all here. I focus on a few directly relevant to the archaeology of inequality. Taken together, their most important results are the changes across the four production modes in the kinds of wealth present and how they are transmitted. Wealth among hunter-gatherers and horticulturalists is primarily embodied and relational, while among pastoralists and intensive agriculturalists, it is principally material, suggesting that contrasts across these production modes in the strength of wealth differences are the consequence of the predominant forms of wealth being transferred rather than, for example, the presence or absence of economic surpluses. Large surpluses are commonly invoked to explain why extreme levels of inequality seem correlated primarily, although not always, with intensive agriculture. In the absence of intensive agriculture, it becomes necessary to invoke environmental richness and/or stability to explain surplus production. These results appear to make that argument unnecessary, shifting the explanatory focus to the hows and whys of the evolution of material wealth.

I am concerned here primarily with the hunter-gatherer study (Smith et al. 2010). The hunter-gatherer sample is small, including only five groups: the Ache, Hadza, Ju'hoansi, Lamalera, and Meriam. Despite this small sample, the authors are able to show that, even in classic "egalitarian" groups, the children of wealthy parents are themselves more likely to be wealthy, whatever form wealth takes, while the offspring of poorer parents will themselves be poorer. Smith et al.'s Gini coefficients, while not large, are not insubstantial, leading them to question the stereotype of foragers as egalitarian and little concerned with wealth. A study of dental wealth among the Efe, Aka, and Mbuti (Hewlett and Walker 1991; Walker and Hewlett 1990), who are generally epitomes of egalitarian organization, although not cited by Smith et al., lends independent support for their conclusions. Walker and Hewlett (1990) examined the dental health of members of all three groups as a proxy measure of overall health. Healthy dentition of course reflects a lifetime of health; bad teeth do not become good teeth. Walker and Hewlett found that dental health varied along two dimensions, gender and status. Women had 
poorer dentition than men. Men who were leaders (i.e., with higher prestige) had significantly better teeth than did those who were not leaders. Additionally, Aka leaders are, on average, $3 \mathrm{~cm}$ taller than the average Aka male (Hewlett 1988). Walker and Hewlett propose that the gender differences reflect women having more carbohydrates in their diets. There are no visible prestige-based dietary differences. However, the likelihood is that the prestige-related differences reflect greater amounts of meat in the diet. High-prestige individuals come from the largest patrilineages present in a camp, and the resulting greater "kinship resources" affect a range of other resources, including networks and what flows through them. Walker and Hewlett hypothesize that the larger kin network gives individuals lifelong access to a relatively greater range of foods, including meat, which would contribute to sustained dental health. In this case, embodied and relational wealth interact. The point here, however, is that this case study provides additional empirical support for their conclusions, which are a second important result of their work.

Further support for the importance of embodied wealth in general comes not from hunter-gatherers but from Marmot's (2004) seminal studies of the health differences among people in finely graded status systems: civil service bureaucracies in which even people in immediately adjacent ranks have different levels of good health, with health declining as one goes down the ranks. Of course, as these and other authors (e.g., Hajda 1984; Suttles 1960) note, some hunter-gatherers also transfer material wealth, as on the Northwest Coast, where massive amounts of material household wealth were transferred from generation to generation and could, under some conditions, accumulate.

Smith et al.'s results have significant methodological implications for archaeological efforts to track the evolution of inequality. Archaeologists generally assume that egalitarianism is the default human social organization in small-scale societies, and they take the absence of evidence for permanent inequality as evidence for egalitarianism. Thus, the archaeology of egalitarianism is based on negative evidence. Evidence for inequality is primarily material wealth (Ames 2007). Developing archaeological evidence and samples for embodied and relational wealth transfers will be difficult, as the Efe, Mbuti, and Aka examples show. Thus, Bowles, Smith, and Borgerhoff Mulder (2010) note that there is little or no evidence of economic differentiation before 24,000 years ago. Most researchers would probably agree that there really is not much evidence before the Holocene. However, given these papers, we should rephrase that to say that we do not see much evidence of material wealth transfers before 24,000 and that we simply do not know much of anything about em- bodied or relational wealth transfers, which would likely be the dominant forms of wealth transfers during the Late Pleistocene.

The issue of archaeologically operationalizing the concepts developed in these papers is not a small one. The samples are small, and many classes of society, particularly among huntergatherers, are poorly represented ethnographically, if at all. The quantification techniques are not altogether transparent. Applying their approach to complex hunter-gatherers, for example, will require ethnography and ethnohistory but primarily archaeology. I am also concerned that the shift in wealth transfers from relational and embodied to material will become reified into stages or culture types rather than being a goad to research.

\section{References Cited}

Ames, Kenneth M. 2007. The archaeology of rank. In Handbook of archaeological theories. Robert A. Bentley, Herbert D. G. Maschner, and Christopher Chippendale, eds. Pp. 487-514. Lanham, MD: AltaMira.

Bowles, Samuel, Eric Alden Smith, and Monique Borgerhoff Mulder. 2010. The emergence and persistence of inequality in premodern societies: introduction to the special section. Current Anthropology 51(1):7-17.

Hajda, Yvonne. 1984. Regional social organization in the Greater Lower Columbia, 1792-1830. PhD dissertation, University of Washington, Seattle.

Hewlett, Barry. 1988. Sexual selection and paternal investment among Aka Pygmies. In Human reproductive behavior. Laura Betzig, Monique Borgerhoff Mulder, and Paul Turek, eds. Pp. 263-276. Cambridge: Cambridge University Press.

Hewlett, Barry, and Phillip L. Walker. 1991. Social status and dental health among the Aka and Mbuti Pygmies. American Anthropologist 93(4):943-944.

Marmot, Michael. 2004. The status syndrome: how social standing affects our health and longevity. New York: Holt.

Smith, Eric Alden, Kim Hill, Frank W. Marlowe, David Nolin, Polly Wiessner, Michael Gurven, Samuel Bowles, Monique Borgerhoff Mulder, Tom Hertz, and Adrian Bell. 2010. Wealth transmission and inequality among huntergatherers. Current Anthropology 51(1):19-34.

Suttles, Wayne. 1960. Affinal ties, subsistence and prestige among the Coast Salish. American Anthropologist 62: 296-305.

Walker, Phillip L., and Barry S. Hewlett. 1990. Dental health and social status among central African foragers and farmers. American Anthropologist 92(2):383-398. 